\title{
Influence of irradiation with Er:YAG laser on the shear bond strength of a resin cement to feldspathic ceramic - in vitro study
}

\section{(Influência da irradiação com laser Er:YAG na resistência ao cisalhamento de um cimento resinoso à cerâmica feldspática - estudo in vitro)}

\author{
M. C. Loffredo ${ }^{l}$, F. S. Hanashiro ${ }^{2}$, W. Steagall Júnior ${ }^{2}$, M. N. Youssef ${ }^{1,2}$, W. C. de Souza-Zaroni ${ }^{l}$ \\ ${ }^{1}$ School of Dentistry, Cruzeiro do Sul University, S. Paulo, SP, Brazil \\ ${ }^{2}$ Department of Restorative Dentistry, School of Dentistry, University of S. Paulo - USP, S. Paulo, SP, Brazil
}

\begin{abstract}
Although several conventional surface treatments have been used on feldspathic ceramic, a few studies investigated the effects of the irradiation with Er: YAG laser using different parameters. The aim of this in vitro study was to evaluate the shear bond strength of a resin cement to feldspathic ceramic, after the application of different surface treatments, especially the irradiation with Er:YAG laser. Forty-two discs made of a feldspathic ceramic were divided into six groups $(\mathrm{n}=7)$ : G1: control group - $10 \%$ hydrofluoric acid (HF), G2: Air abrasion with $\mathrm{Al}_{2} \mathrm{O}_{3}+\mathrm{HF}$; G3: Er: YAG laser with $500 \mathrm{~mJ} / 4 \mathrm{~Hz}$, G4: Er: YAG laser with $500 \mathrm{~mJ} / 4 \mathrm{~Hz}$ : + HF; G5: Er: YAG laser with $400 \mathrm{~mJ} / 6 \mathrm{~Hz}$ and G6: Er:YAG laser with $400 \mathrm{~mJ} / 6 \mathrm{~Hz}+\mathrm{HF}$. After this, all the specimens were treated with silane, and then a resin cement cylinder was built on the treated ceramic surface. After $24 \mathrm{~h}$ at $37^{\circ} \mathrm{C}$, specimens were submitted to the shear bond strenght test and stereoscopic evaluation to determine the type of failure. The mean bond strength values (MPa) obtained were: G1 - 17.55, G2 - 18.80, G3 - 21.80, G4 - 12.62, G5 - and 15.81 G6- 11.59. After performing the ANOVA and Tukey's test, it was concluded that the group irradiated with Er:YAG laser at $500 \mathrm{~mJ} / 4 \mathrm{~Hz}$ performed similarly to the groups that received the conventional treatments, such as hydrofluoric acid etching and the combination of air abrasion plus hydrofluoric acid, and was higher than the other groups irradiated with Er:YAG laser.
\end{abstract}

Keywords: feldspathic ceramic, Er:YAG laser, aluminum oxide, hydrofluoric acid.

Resumo

O objetivo deste estudo in vitro foi avaliar a resistência ao cisalhamento de um cimento resinoso à cerâmica feldspática, após a aplicação de diferentes tratamentos de superfície, especialmente a irradiação com laser de Er:YAG. Quarenta e dois discos de cerâmica foram divididos em seis grupos $(n=7)$ : G1- grupo controle: ácido fluorídrico a 10\% (HF), G2 - jato abrasivo de $\mathrm{Al}_{2} \mathrm{O}_{3}$ + HF; G3 - Er:YAG laser com 500 mJ/4Hz (L1); G4- L1 + HF; G5 - Er:YAG laser com 400 mJ/6Hz (L2) e G6 - L2 + HF. Depois disso, todas as amostras foram tratadas com silano e, em seguida, um cilindro de cimento resinoso foi construído sobre a superfície de cerâmica tratada. Depois de 24 ha $37{ }^{\circ} \mathrm{C}$, os espécimes foram submetidos ao teste de resistência ao cisalhamento e avaliação estereoscópica para determinar o tipo de fratura. Os valores médios de resistência de união (MPa) obtidos foram: G1 - 17,55, G2 - 18,80, G3 - 21,80, G4 - 12,62, G5 - 15,81 e G6- 11,59. Após análise de variância e teste de Tukey, concluiu-se que o grupo irradiado com laser de Er:YAG laser com $500 \mathrm{~mJ} / 4 \mathrm{~Hz}$ obteve resultados semelhantes aos grupos que receberam os tratamentos convencionais e foi maior do que os outros grupos irradiados com laser de Er:YAG.

Palavras-chave: cerâmica feldspática, laser de Er:YAG, óxido de alumínio, ácido fluorídrico.

\section{INTRODUCTION}

Ceramic restorations are outstanding among the innumerable existent esthetic treatments, as they make it possible to restore form and function in both anterior and posterior teeth. The excellent esthetic quality of this type of restoration is due to its natural appearance and lasting chemical and optical properties [1,2], with its main characteristics being fluorescence, translucence, radiopacity, biocompatibility [3], high compressive strength and a heat expansion coefficient similar to that of the dental structure. These are the characteristics that enable it to be used without metals. Nevertheless, pure ceramic restorations are very fragile and extremely susceptible to the occurrence of fractures if they are not cemented with a material that presents adhesive properties. The retention of ceramic restorations depends almost exclusively on chemical and mechanical bond to the resin cement. Therefore, one of the factors for the success of this type of restoration lies in the effectiveness of this bond [4-9]. The bond strength between the resin cement and ceramic depends on many factors, such as the composition of the ceramic, resin cement and silane agent used, in addition to the surface treatment performed on the ceramic.

As regards ceramic surface treatments, various options have been suggested, and these are generally combinations 
of various methods of mechanical and chemical conditioning used to improve the bond strength at the ceramic/resin cement interface.

One type of chemical conditioning can be performed with the application of $10 \%$ hydrofluoric acid (HF), which is capable of creating irregularities on the porcelain surface, enabling micromechanical interlocking to be obtained between the resin cement and ceramic [10]. However, studies have indicated that HF must be used with caution in clinical situations, because it is caustic and may cause damage to soft tissues [11, 12]. Roughening the ceramic surface with airborne aluminum oxide particles or diamond tips is generally considered mandatory for obtaining correct bond strength $[13,14]$. Another surface treatment technique that has shown to be very promising is laser irradiation. Various types of laser may be used in dental procedures, however, erbium laser (Er:YAG) is one of the most recommended for use on dental hard tissues, because its wavelength (2.94 $\mu \mathrm{m})$ coincides with the main absorption band of water $(\sim$ $3,0 \mu \mathrm{m})$ and it is also well absorbed by the $\mathrm{OH}^{-}$grouping in hydroxyapatite $[15,16]$. Due to its good interaction with dental structures, Er:YAG laser may be a good option for repair procedures in ceramic restorations. The bond strength to ceramic conditioned with Er:YAG laser was evaluated [17], and in this experiment, the bond strength was only effectively higher when the laser was used in conjunction with hydrofluoric acid etching. In a similar manner, it was observed that irradiating feldspathic ceramic specimens with Er:YAG laser associated with prior airborne aluminum oxide particle abrasion was superior to using laser alone, however, it was not superior to conventional treatments with hydrofluoric acid or air abrasion used alone [18].

On the other hand, it was verified that with the use of a hydroxyapatite-based paste on the surface to be irradiated, the action of Er:YAG laser could be potentiated when used after airborne aluminum oxide particle abrasion on feldspathic ceramic surfaces [19]. Thus, effective bonding similar to that obtained with conventional treatment with air abrasion and hydrofluoric acid, and air abrasion and irradiation with Nd:YAG laser was achieved.

In this context, since the type of surface treatment performed on a feldspathic ceramic surface could affect the bond strength of indirect restorations made with pure ceramic, it is necessary to conduct researches that establish the effects that different parameters of Er:YAG laser used for surface treatment, exert on the bond to ceramic using conventional resin cements.

\section{MATERIALS AND METHODS}

Forty-two feldspathic ceramic discs, $5 \mathrm{~mm}$ in diameter and $4 \mathrm{~mm}$ thick (Ceramco 3, Dentsply, York, USA) were fabricated according to the manufacturer's recommendations. The specimens were embedded in acrylic resin blocks, and the porcelain surface was covered with transparent tape to prevent contamination during embedding. After this, the exposed surfaces were flattened in a polishing machine
(EcoMet ${ }^{\circledR}$ Twin, Buehler, Illinois, USA), under water cooling, using 600 grit sandpaper, and then immediately immersed in distilled water at $37{ }^{\circ} \mathrm{C}$ for $24 \mathrm{~h}$. After this, the specimens were randomly assigned to one of six groups $(\mathrm{n}=7)$ of surface treatments:

Group 1 (control group - HF): etched with 10\% hydrofluoric acid (Dentsply Ind. Com. Ltda., Petrópolis, RJ, Brazil) for $2 \mathrm{~min}$.

Group $2\left(\mathrm{Al}_{2} \mathrm{O}_{3}+\mathrm{HF}\right)$ : air abrasion (MicroEtcher; Danville Engineering, San Ramon, California, USA) with $50 \mu \mathrm{m}$ aluminum oxide was applied for $10 \mathrm{~s}$ at an operating distance of $4 \mathrm{~cm}$ from the ceramic surface, at 2 bar pressure and etched with 10\% hydrofluoric acid (Dentsply Ind. Com. Ltda., Petrópolis, RJ, Brazil) for $2 \mathrm{~min}$.

Group 3 (Er:YAG laser $500 \mathrm{~mJ} / 4 \mathrm{~Hz}$ ): Er:YAG laser (Kavo Key Laser II model, KavoDental GmbH \& Co., Biberach, Germany) irradiation with wavelength $2.94 \mu \mathrm{m}$. The laser beam was delivered in focused mode at a focal distance $0.5 \mathrm{~mm}$, with $500 \mathrm{~mJ}$ of energy per pulse, at a frequency $4 \mathrm{~Hz}$, and the entire ceramic area was manually scanned for $40 \mathrm{~s}$ without water spray.

Group 4 (Er:YAG laser $500 \mathrm{~mJ} / 4 \mathrm{~Hz}+\mathrm{HF}$ ): Er:YAG laser irradiation as described in Group 3 was followed by application of $10 \%$ hydrofluoric acid as described in Group 1.

Group 5 (Er:YAG laser $400 \mathrm{~mJ} / 6 \mathrm{~Hz}$ ): Er:YAG laser (Kavo Key Laser II model, KavoDental GmbH \& Co., Biberach, Germany) irradiation with wavelength $2.94 \mu \mathrm{m}$. The laser beam was delivered in focused mode at a focal distance $0.5 \mathrm{~mm}$, with $400 \mathrm{~mJ}$ of energy per pulse, at a frequency $6 \mathrm{~Hz}$, and the entire ceramic area was manually scanned for $40 \mathrm{~s}$ without water spray.

Group 6 (Er:YAG laser $400 \mathrm{~mJ} / 6 \mathrm{~Hz}+\mathrm{HF}$ ): Er:YAG laser irradiation as described in Group 5 was followed by application of $10 \%$ hydrofluoric acid as described in Group 1 .

The sandblasting with aluminum oxide particles and irradiation with Er: YAG laser was performed manually by the same operator, who trained and practiced this method, in order to promote a better standardization of the distance from the ceramic surface [20], obtaining always comparable experimental results.

All the specimens etched with $10 \%$ hydrofluoric acid were subsequently thoroughly rinsed with distilled water for $10 \mathrm{~s}$ to remove the residual acid and then air-dried.

After the surface treatments, a silane agent (Silano, Coupling Agent, Dentsply Ind. Com. Ltda., Petrópolis, RJ, Brazil) was applied according to the manufacturer instructions. After this, a resin cement (RelyX ${ }^{\mathrm{TM}}$ ARC, 3M ESPE, Dental products, Seefeld, Germany), was applied according to manufacturer recommendation. Samples were then inserted into rubber-ring matrices $(3 \mathrm{~mm}$ in diameter and $3 \mathrm{~mm}$ thick) and positioned firmly onto the center of the ceramic disks. Then, the resin cement was inserted into the matrix with a syringe and initially polymerized, using a light-polymerizing unit (Elipar Freelight 2, 3M ESPE, St Paul, MN, USA) with the light directed perpendicularly to the resin cement for $40 \mathrm{~s}$. The rubber matrix was then carefully removed and polymerization was completed 
with $20 \mathrm{~s}$ polymerization sequences, per surface around the circumference of the cement cylinder, resulting in a total polymerization time of $100 \mathrm{~s}$ for each specimen. After the bonding procedures, light intensity output was measured with a radiometer (Demetron curing Radiometer 100, Kerr Demetron, Danbury, CT, USA), maintaining $600 \mathrm{~mW} / \mathrm{cm}^{2}$.

The specimens were stored in distilled water at $37{ }^{\circ} \mathrm{C}$ for $24 \mathrm{~h}$. The samples were then submitted to a shear bond strength test (Mini-Instron 4442, Instron Corp., Norwood, MA, USA), with a load cell of $50 \mathrm{kgf}$ and a cross-head speed of $0.5 \mathrm{~mm} / \mathrm{min}$. After the shear bond strength test, ceramic bonding areas were analyzed under a stereoscopic optical magnifier (Nikon 88286, 40X, Nikon, Kawasaki, Kanagawa, Japan) to assess the type of failure. This analysis enabled three types of failures to be defined: adhesive failure was considered when it occurred at the ceramic/resin cement interface; cohesive failure, when it occurred in the resin cement or ceramic, with no damage to the interface; and mixed failure was defined as involving both the interface and the material. After this analysis, one specimen of each group was sputter-coated with a goldpaladium alloy (Hummer VI Sputtering System, Anatech Ltd., Alexandria, VA, USA), examined under SEM at 15 kV (JSM-35CF, Jeol Ltd., Tokyo, Japan) and photografed

Table I - One-way ANOVA of the experimental treatments, for the shear bond strength data.

[Tabela I - Análise de variância de fator único, para os tratamentos experimentais de superfície, da variável resistência adesiva ao cisalhamento.]

\begin{tabular}{cccccc}
\hline $\begin{array}{c}\text { Source of } \\
\text { Variation }\end{array}$ & df & SS & MS & F obt. & P - Value \\
\hline Treatments & 5 & 518.84 & 103.77 & 8.58 & $2.00 \mathrm{E}-05^{*}$ \\
$\quad \begin{array}{l}\text { Error } \\
\text { Residual) }\end{array}$ & 36 & 435.32 & 12.09 & & \\
$\quad$ Total & 41 & 954.16 & & & \\
\hline
\end{tabular}

$d f=$ degrees of freedom; $S S=$ Sum of squares; $M S=$ Mean square.

$g l=$ graus de liberdade $; Q=$ Soma dos quadrados; $Q M=$ Médio quadrático.. at magnification $\times 500$.

The averages of each group were analyzed by oneway analysis of variance (ANOVA) and Tukey HSD test to determine the significant differences between the conditioning methods, at the significance level of $\mathrm{p}<0.05$.

\section{RESULTS}

Shear bond strength test: ANOVA (Table I) showed a significant result, being $\mathrm{F}(5.36)=8.58, \mathrm{p}<0.05$. This indicated that there was at least one statistically significant difference among the different levels of the experimental treatments with regard to the bond strength values. The hypothesis of nullity $\mathrm{H} 0$ was therefore rejected, and the alternative hypothesis $\mathrm{H} 1$ was accepted.

In order to exactly identify the possible differences among the various experimental treatments, the Tukey HSD multiple comparisons test was applied, at 5\%. Table II shows the multiple comparisons, and Fig. 1 illustrates the differences among the experimental treatments. Initially, the results showed that Group $6\left(11.59 \mathrm{MPa} \pm 3.46^{\mathrm{A}}\right)$ presented the lowest bond strength values and Group $3(21.80 \mathrm{MPa} \pm$ $2.58^{\mathrm{D}}$ ), the highest.

The non-irradiated groups, $1\left(17.55 \mathrm{MPa} \pm 3.94^{\mathbf{B , C ,}, \mathbf{D}}\right)$ and $2\left(18.80 \mathrm{MPa} \pm 2,60^{\mathrm{C}, \mathrm{D}}\right)$, were not statistically different from each other and did not differ from some of the irradiated groups. The Control group was not statistically different from groups $4\left(12.62 \mathrm{MPa} \pm 3.58^{\mathrm{A}, \mathbf{B}}\right), 5\left(15.81 \mathrm{MPa} \pm 4.33^{\mathrm{A}, \mathbf{B}, \mathbf{C}}\right)$ and $3\left(21.80 \mathrm{MPa} \pm 2.58^{\mathrm{D}}\right)$, whereas Group 2, was not statistically different from Group $5\left(15.81 \mathrm{MPa} \pm 4.33^{\mathrm{A}, \mathbf{B}, \mathbf{C}}\right)$ and Group 3 $\left(21.80 \mathrm{MPa} \pm 2.58^{\mathrm{D}}\right)$.

Taking into consideration whether or not hydrofluoric acid was used, it can be observed that in the irradiated groups, using the same parameters, the groups irradiated with $400 \mathrm{~mJ} / 6 \mathrm{~Hz}$ presented no statistical difference, whereas the groups irradiated with $500 \mathrm{~mJ} / 4 \mathrm{~Hz}$ differed, with higher values for the group without the application of HF, group 3 ( $21.80 \mathrm{MPa} \pm 2.58^{\mathrm{D}}$ ) and lower values for the group with the application of HF, group 4 (12.62 $\left.\mathrm{MPa} \pm 3.58^{\mathrm{A}, \mathbf{B}}\right)$. When comparing the different irradiation

Table II -Tukey (HSD) multiple comparison test table of the experimental treatments.

[Tabela II - Teste de múltipla comparação de Tukey (HSD para os tratamentos experimentais de superfície.]

\begin{tabular}{|c|c|c|c|c|c|}
\hline Experimental Treatments & $\mathrm{N}$ & $\mathbf{A}$ & B & $\mathbf{C}$ & D \\
\hline $\mathrm{G} 6-400 \mathrm{~mJ} / 6 \mathrm{~Hz}+\mathrm{HF}^{\mathrm{A}}$ & 7 & $11.59 \pm 3.4$ & & & \\
\hline $\mathrm{G} 4-500 \mathrm{~mJ} / 4 \mathrm{~Hz}+\mathrm{HF}^{\mathbf{A}, \mathbf{B}}$ & 7 & $12.62 \pm 3.5$ & $12.62 \pm 3.5$ & & \\
\hline $\mathrm{G} 5-400 \mathrm{~mJ} / 6 \mathrm{~Hz}^{\mathrm{A}, \mathbf{B}, \mathbf{C}}$ & 7 & $15.81 \pm 4.3$ & $15.81 \pm 4.3$ & $15.81 \pm 4.3$ & \\
\hline G1 - Control $\mathbf{B , C , D}$ & 7 & & $17.55 \pm 3.9$ & $17.55 \pm 3.9$ & $17.55 \pm 3.9$ \\
\hline $\mathrm{G} 2-\mathrm{Al}_{2} \mathrm{O}_{3}+\mathrm{HF}^{\mathbf{C}, \mathbf{D}}$ & 7 & & & $18.80 \pm 2.6$ & $18.80 \pm 2.6$ \\
\hline $\mathrm{G} 3-500 \mathrm{~mJ} / 4 \mathrm{~Hz}{ }^{\mathrm{D}}$ & 7 & & & & $21.80 \pm 2.5$ \\
\hline P-Value & & $23.10 \%$ & $11.00 \%$ & $59.80 \%$ & $22.60 \%$ \\
\hline
\end{tabular}

Means with different superscript letters showed statistically significant difference from each other.

Data are displayed as Mean (in MPa) \pm Standard Deviation.

Médias com letras diferentes mostraram diferença estatisticamente significante entre elas.

Os dados estão dispostos em média \pm desvio-padrão. 


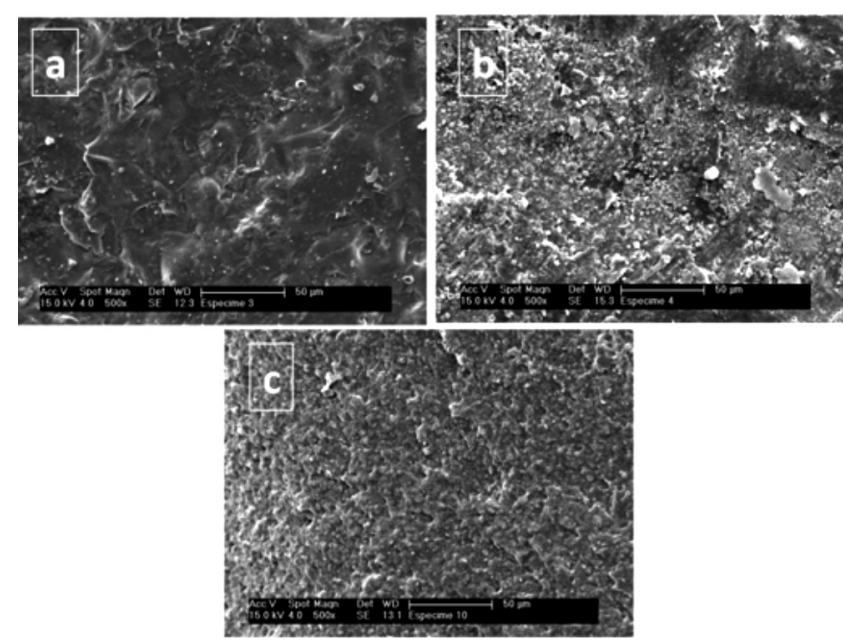

Figure 1: SEM images of feldspathic ceramic surfaces after different treatments: a - Group 1 (control group - HF), b - Group 2 $\left(\mathrm{Al}_{2} \mathrm{O}_{3}+\mathrm{HF}\right)$ and c - Group 3 (Er:YAG laser $\left.500 \mathrm{~mJ} / 4 \mathrm{~Hz}\right)$.

[Figura 1: Imagens de microscopia eletrônica de varredura de superfícies de cerâmica feldspática após diferentes tratamentos: $a$ - Grupo 1 (grupo controle - HF), b-Grupo $2\left(\mathrm{Al}_{2} \mathrm{O}_{3}+\mathrm{HF}\right)$ e c Grupo 3 (laser Er:YAG $500 \mathrm{~mJ} / 4 \mathrm{~Hz}$ ).]

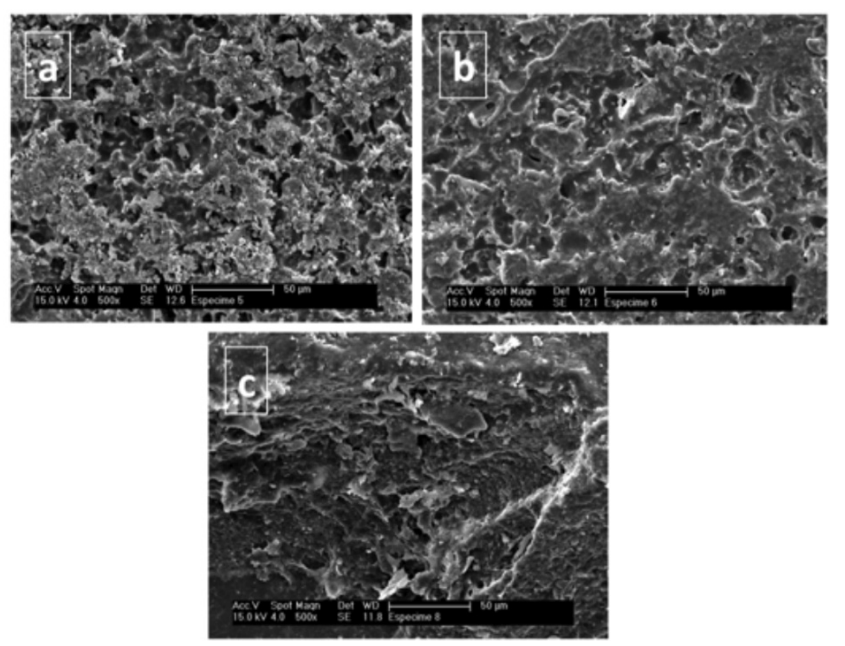

Figure 2: SEM images of feldspathic ceramic surfaces after different treatments: a - Group 4 (Er:YAG laser $500 \mathrm{~mJ} / 4 \mathrm{~Hz}+$ HF), b - Group 5 (Er:YAG laser $400 \mathrm{~mJ} / 6 \mathrm{~Hz}$ ) and c - Group 6 (Er:YAG laser $400 \mathrm{~mJ} / 6 \mathrm{~Hz}+\mathrm{HF}$ ).

[Figura 2: Imagens de microscopia eletrônica de varredura de superfícies de cerâmica feldspática após diferentes tratamentos: a - Grupo 4 (laser Er:YAG 500 mJ/4 Hz + HF), b - Grupo 5 (laser Er:YAG $400 \mathrm{~mJ} / 6 \mathrm{~Hz}$ ) and c - Grupo 6 (laser Er:YAG $400 \mathrm{~mJ} / 6 \mathrm{~Hz}$ $+H F)$.]

parameters, the groups $6\left(11.59 \mathrm{MPa} \pm 3.46^{\mathrm{A}}\right), 4(12.62$ $\left.\mathrm{MPa} \pm 3.58^{\mathbf{A}, \mathbf{B}}\right)$ and $5\left(15.81 \mathrm{MPa} \pm 4.33^{\mathbf{A}, \mathbf{B}, \mathbf{C}}\right)$, were not statistically different among them, showing statistically lower values in comparison with group $3(21.80 \mathrm{MPa} \pm$ $\left.2.58^{\mathrm{D}}\right)$.

Failure type analysis: In the analysis of the types of failures that occurred at the ceramic/ resin cement interface, it was observed that the groups 1,2,3,4 and 6 presented only cohesive failures in the ceramic. Only Group 5 presented $57.14 \%$ of mixed failures and the others were cohesive failures in the ceramic.

SEM analysis: SEM analysis showed that Group 1 produced slight irregular surface (Fig. 1a), whereas Groups 2 and 3 produced a moderate amount of surface relief (Figs. $1 \mathrm{~b}$ and $1 \mathrm{c}$, respectively). Groups 4, 5 and 6 produced the surface relief with severe undercuts, which were increasing from Group 4 to Group 6 (Figs. 2a, 2b and 2c, respectively).

\section{DISCUSSION}

The bond strength of resin cement to the tested feldspathic ceramic is dependent on the surface treatment. Thus, it could be verified that in the control group treated with hydrofluoric acid only, the bond strength values were similar to those of the groups with the best bond performance, these being: $\mathrm{Al}_{2} \mathrm{O}_{3}+\mathrm{HF}$ and Er:YAG laser operating in $500 \mathrm{~mJ} / 4 \mathrm{~Hz}$. However, the control group did not differ from the groups with lower bond strength performance, such as the groups irradiated with Er:YAG laser $400 \mathrm{~mJ} / 6 \mathrm{~Hz}$ and $500 \mathrm{~mJ} / 4 \mathrm{~Hz}$ $+\mathrm{HF}$.

Among the chemical treatments that could be used for etching the feldspathic ceramic surface, etching with hydrofluoric acid is one of the most used methods [10,21-23]. Hydrofluoric acid acts on the vitreous phase of the ceramic, partially dissolving it and creating retentions in the form of micropores, by exposing the areas of crystals that compose the crystalline phase [24]. These micropores increase the surface area and make it possible for micromechanical interlocking of the resin cement to occur.

With the intention of providing chemical stability between the ceramic and resin cement, the use of a silane agent has been recommended for chemically bonding the vitreous component of ceramics $\left(\mathrm{SiO}_{2}\right)$ to the resin cement. During the process of silane interaction with $\mathrm{SiO}_{2}$, the ceramic surface becomes hydrophobic and organophilic, this process being of the utmost importance in favoring intimate contact with the resinous materials. Therefore, because of being a bifunctional molecule, silane is capable of uniting with the inorganic component $\left(\mathrm{SiO}_{2}\right)$ of the ceramic and to the organic component (methacrylate group) of the resinous materials [25]. Therefore, the use of the silane agent is fundamental for improving the bond between $\mathrm{SiO}_{2}$-based ceramics, as is the case of feldspathic ceramics, and resin cements [24]. The study results developed by Stewart et al. [26], in this context, have demonstrated that hydrofluoric acid-etching followed by silane application produced the best bonds $(15.0 \pm 7.4$ to $21.8 \pm 5.8 \mathrm{MPa})$ at 24 $\mathrm{h}$ and 6 months of storage with all 4 resin cements tested for bonding to the Ceramco ceramic discs. These results are in agreement with the ones found in the present study, which have observed mean bond strength of $18.80 \pm 2.6 \mathrm{MPa}$ for the group that used the same association (control group) for a similar ceramic.

Several studies $[13,27,28]$ have verified that the association of $\mathrm{HF}$ and a silane agent is the most effective 
surface treatment, although this is not always statistically better than the other treatments involving roughening of this surface, followed by silane application. Considering that silane agent application was performed in all the groups, this affirmation corroborates the results observed in the present study, since the result of the control group (HF) was similar to those of the $\mathrm{Al}_{2} \mathrm{O}_{3}+\mathrm{HF}$ and Er:YAG Laser $500 \mathrm{~mJ} / 4 \mathrm{~Hz}$ group. As regards group $\mathrm{Al}_{2} \mathrm{O}_{3}+\mathrm{HF}$, in the literature it has been observed that the use of air abrasion is a prerequisite to promote the bond between ceramics and resin cements [19]. Among the existent types of airborne particle abrasion, the type with aluminum oxide particles has usually been used to clean and promote micromechanical retention to ceramics [3, 29-31], being the initial procedure performed by prosthetic laboratories indicated for use before the process of adhesive cementation of indirect restorations. Nevertheless, neither hydrofluoric acid etching nor the association $\mathrm{Al}_{2} \mathrm{O}_{3}$ $+\mathrm{HF}$ were superior to irradiating the ceramic surface with Er:YAG laser $500 \mathrm{~mJ} / 4 \mathrm{~Hz}$. This finding allows one to affirm that Er:YAG laser may be a promising tool for feldspathic ceramic surface treatment, particularly when dealing with repair procedures of ceramic restorations already cemented to the dental structure.

In intraoral procedures for the repair of ceramic restorations, hydrofluoric acid must be used very cautiously, as this acid consists of dangerous components that are irritating to oral soft tissues [32,33]. Whereas, air abrasion is characterized as being a procedure that involves a great deal of manual dexterity by the professional, so that excessive wear does not occur in integral regions of the ceramic restoration. In addition, it is necessary to use high powered suction equipment to remove the aluminum oxide particles to avoid any type of discomfort to the patient during the procedure.

The clinical use of Er:YAG laser on dental substrate has been well established in the literature, as it acts by thermomechanical ablation, vaporizing the water that constitutes the tissues $[15,16]$. This vaporization causes an expansion followed by microexplosions, that produces the ejection of both organic and inorganic particles from these tissues, promoting the appearance of a dentinal surface with open tubules and without smear layer [23, 34] and an irregular enamel surface. These alterations promote an increase in the penetration of resin monomers and favor the bond to these substrates $[35,36]$. From this, it seems that this laser can be used to create irregularities on ceramics' surface from different types, and enhance the bond strength between these materials and resin cements $[18,19,37]$.

In a previous study [18] it has been used the same laser equipment operating in $500 \mathrm{~mJ} / 4 \mathrm{~Hz}$ for $2 \mathrm{~min}$ on feldspathic ceramic surfaces and it was observed low bond strength (mean shear bond strength was $3.67 \mathrm{MPa}$ ), this being similar to the group that received no type of treatment (4.15 MPa), and also those that were etched with phosphoric acid (3.08 $\mathrm{MPa}$ ) or acidulated phosphate fluoride (5.41 MPa). On the other hand, it has been verified that with the introduction of a hydroxyapatite-based paste on the ceramic surface before irradiation with the same laser $(500 \mathrm{~mJ} / 4 \mathrm{~Hz}$ for 20 s) promoted bond strength values (11.18 MPa) similar to those of the group treated with the association of air abrasion with $\mathrm{Al}_{2} \mathrm{O}_{3}$ particles + $\mathrm{HF}(10.71 \mathrm{MPa})$ [19]. Based on these previous studies, the proposal of the present study was to use an intermediate irradiation time (40 s), varying the energy and frequency, without the use of hydroxyapatite paste. In this context, it was observed that Groups $400 \mathrm{~mJ} / 6$ $\mathrm{Hz}, 400 \mathrm{~mJ} / 6 \mathrm{~Hz}+\mathrm{HF}$, and $500 \mathrm{~mJ} / 4 \mathrm{~Hz}+\mathrm{HF}$ showed similar values among them and statistically lower values in comparison with Group $500 \mathrm{~mJ} / 4 \mathrm{~Hz}$, which showed the influence of both the frequency of pulses used and whether or not hydrofluoric acid etching was performed. However, all irradiated groups of this study presented higher bond strength means (minimum of 11.59 and maximum of $21.80 \mathrm{MPa}$ ) when compared to the previous studies [19].

When one analyzes the influence of the frequency of pulses and energy density on the capacity of Er:YAG laser to remove the substrate that is being irradiated, one observes studies in the literature [38-40] that affirm that the increase in the pulse repetition rate seems to influence the effectiveness of dental tissue removal more intensely than the increase in energy. This finding is in agreement with the results that were verified in the present study, in which Group 400 $\mathrm{mJ} / 6 \mathrm{~Hz}$ presented lower bond strength values than group $500 \mathrm{~mJ} / 4 \mathrm{~Hz}$, a fact that can probably be explained by the larger removal of ceramic substrate in the group in which the larger frequency of pulses was used. This may have caused the formation of extensive areas of porosity (which can be observed on SEM images) that could not be completely filled with adhesive material and resulted in lower bond strength, and the occurrence of $57.14 \%$ of mixed failures in this group. A further experiment should clarify whether the repetition rate itself (potentially via temperature) and the number of pulses per surface area is the essential parameter. A similar fact must have been promoted by the association of irradiation with Er:YAG laser and etching with HF, because when both parameters used were associated with HF, low bond strength values were obtained. However, it was observed that HF acid etching was the most effective surface treatment method for a feldspathic ceramic when compared with laser irradiation with either the Er:YAG or Nd:YAG laser, when using the resin cement Panavia F [41]. Based on this fact, the authors suggested that the laser application should be combined with HF acid etching.

Besides the determination of the adhesion values, the failure modes were examined as well in this study to get further information about the probable success of a pretreatment method under clinical conditions. In general, a cohesive failure mode within the ceramics indicates that the adhesion of the resin material to the ceramic is higher than the shear strength of the ceramic. Due to the fact that the performance of the Ceramco blocks is well established in other studies $[26,42,43]$ with shear bond strengths ranging from 11 to $28 \mathrm{MPa}$ and with flexural stress of $70 \mathrm{MPa}$ [44], the observation of mainly cohesive failure may lead to the conclusion that the adhesion of the resin cement to 
the ceramic, regardless its surface treatment, is sufficient within the limits of this study. Nevertheless, the occurrence of cohesive failures can also be attributed to the bond test employed. Many studies that used conventional shear bond test observed that this methodology often produces fracture away from the adhesion zone [30, 43$]$. Such failures of the substrate prevent measurement of interfacial bond strength and limit further improvements in bonding systems.

Several studies have identified non-uniform stress distributions along bonded interfaces [45-47]. The nonuniform interfacial stress distribution generated for conventional tensile and shear bond strength tests initiate fractures from flaws at the interface or in the substrate in areas of high stress concentration [48]. Therefore, analyzing the results of the present study, one might consider that the surface treatments applied to ceramic could have caused these possible flaws within the body of the ceramic material, and consequently, the occurrence of cohesive failures.

Finally, as the shear bond strength tests in the present study were performed after storing the specimens for only 24 $\mathrm{h}$, it would be interesting to know whether the bond strength values obtained could be maintained through long periods of time, since little is known about the ceramic surface resulting from irradiation with Er:YAG laser. Therefore, further studies are necessary for better elucidation of the effects that this technology could exert on the bond of different ceramic materials to resin cements over the course of time, as well as the clinical feasibility of its application.

\section{CONCLUSION}

The group irradiated with Er:YAG laser with the parameter set to $500 \mathrm{~mJ} / 4 \mathrm{~Hz}$ obtained results similar to the groups that received conventional treatment, such a hydrofluoric acid etching and the association of airborne aluminum oxide particle abrasion and hydrofluoric acid, and was superior to the other groups irradiated with Er:YAG laser.

\section{ACKNOWLEDGMENTS}

We thank Laboratório Júlio for the feldspathic ceramic discs used in this study.

\section{REFERENCES}

[1] J. R. Kelly, I. Nishimura, S. D. Campbell, "Ceramics in dentistry: historical roots and current perspectives", J. Prosthet. Dent. 75 (1996) 18-32.

[2] R. J. Czerw, C. W. Wakefield, J. W. Robbins, M. S. Fulkerson, "Shear bond strength of composite resin to microetched metal with five newer-generation bonding agents", Oper. Dent. 20 (1995) 58-62.

[3] G. A. Borges, A. M. Spohr, M. F. de Goes, L. C. Sobrinho, D. C. Chan, "Effect of corrosion and abrasion of airborne particles in the microstructure of different dental ceramics", J. Prosthet. Dent. 89 (2003) 479-488.
[4] D. Dietschi, P. Magne, J. Holz, "Recent trends in esthetic restorations for posterior teeth", Quintessence Int. 25 (1994) 659-677.

[5] J. A. Sorensen, M. J. Engelman, T. J. Torres, S. P. Avera, "Shear bond strength of composite resin to porcelain", Int. J. Prosthodont. 4 (1991) 17-23.

[6] A. N. Ozden, F. Akaltan, G. Can, "Effect of surface treatments of porcelain on the shear bond strength of applied dual-cured cement”, J. Prosthet. Dent. 72 (1994) 85-88.

[7] K. Sato, H. Matsumura, M. Atsuta, "Effect of threeliquid bonding agents on bond strength to a machine-milled ceramic material”, J. Oral Rehabil. 26 (1999) 570-574.

[8] J. H. Chen, H. Matsumura, M. Atsuta, "Effect of etchant, etching period, and silane priming on bond strength to porcelain of composite resin", Oper. Dent. 23 (1998) 250257.

[9] A. Della Bona, K. J. Anusavice, J. A. A. Hood, "Effect of ceramic surface treatment on tensile bond strength to a resin cement", Int. J. Prosthodont. 15 (2002) 248-253.

[10] M. Özcan, H. N. Alkumru, D. Gemalmaz, "The effect of surface treatment on the shear bond strength of luting cement to a glass-infiltrated alumina ceramic", Int. J. Prosthodont. 14 (2001) 335-339.

[11] D. F. Tylka, G. P. Stewart, "Comparison of acidulated phosphate fluoride gel and hydrofluoric acid etchants for porcelain-composite repair", J. Prosthet. Dent. 72 (1994) 121-127

[12] S. Shahverdi, S. Canay, E. Sahin, A. Bilge, "Effects of different surface treatment methods on the bond strength of composite resin to porcelain”, J. Oral Rehabil. 25 (1998) 699-705.

[13] K. A. Kupiec, K. M. Wuertz, W. W. Barkmeier, T. M. Wilwerding, "Evaluation of porcelain surface treatments and agents for composite-to-porcelain repair", J. Prosthet. Dent. 76 (1996) 119-124.

[14] M. Özcan, P. Pfeiffer, I. Nergiz, "A brief history and current status of metal-and ceramic surface-conditioning concepts for resin bonding in dentistry", Quintessence Int. 29 (1998) 713-724.

[15] U. Keller, R. Hibst, "Experimental studies of the application of the Er:YAG laser on dental hard substances: II Light microscopic and SEM investigations", Lasers Surg. Med. 9 (1989) 345-351.

[16] L. J. Miserendino, R. M. Pick, Lasers in Dentistry, Eds Quintessence Publishing Co. (1995) 21-22.

[17] B. Gökçe, B. Ozpinar, M. Dündar, E. Comleloglu, B. H. Sen, M. A. Gungor, "Bond strengths of all-ceramics: acid VS laser etchings”, Oper. Dent. 32 (2007) 173-178.

[18] P. Shiu, W. C. Souza-Zaroni, C. P. Eduardo, M. N. Youssef, "Effect of felspathic ceramic surface treatments on bond strength to resin cement", Photomed. Laser Surg. 25 (2007) 291-296.

[19] S. da Silva Ferreira, F. S. Hanashiro, W. C. de SouzaZaroni, M. L. Turbino, M. N. Youssef, "Influence of aluminum oxide sandblasting associated with Nd:YAG or Er:YAG lasers on shear bond strength of a feldspathic ceramic to resin cements", Photomed. Laser Surg. 28 (2010) 471-475.

[20] A. M. Spohr, G. A. Borges, L. H. Júnior, E. G. Mota, H. M. Oshima, "Surface modification of In-Ceram Zirconia ceramic by Nd:YAG laser, Rocatec system, or aluminum oxide sandblasting and its bond strength to a resin cement", 
Photomed. Laser Surg. 26 (2008) 203-208.

[21] T. Hayakawa, K. Horie, M. Aida, H. Kanaya, T. Kobayashi, Y. Murata, "The influence of surface conditions and silane agents on the bond of resin to dental porcelain", Dent. Mater. 8 (1992) 238-240.

[22] D. Estafan, F. Dussetschleger, A. Estafan, W. Jia, "Effect of prebonding procedures on shear bond strength of resin composite to pressable ceramic", Gen. Dent. 48 (2000) 412-416.

[23] M. Özcan, A. Akkaya, 'New approach to bonding allceramic adhesive fixed partial dentures: a clinical report", J. Prosthet. Dent. 88 (2002) 252-254.

[24] M. Aida, T. Hayakawa, K. Mizukawa, "Adhesion of composite to porcelain with various surface conditions", J. Prosthet. Dent. 73 (1995) 464-470.

[25] N. M. Jedynakiewicz, N. Martin, "The effect of surface coating on the bond strength of machinable ceramics", Biomaterials 22 (2001) 749-752.

[26] G. P. Stewart, P. Jain, J. Hodges, "Shear bond strength of resin cements to both ceramic and dentin", J. Prosthet. Dent. 88 (2002) 277-284.

[27] A. H. A. Suliman, E. J. Swift, J. Perdigão, "Effects of surface treatment and bonding agents on bond strength of composite resin to porcelain", J. Prosthet. Dent. 70 (1993) 118-120.

[28] J. W. Thurmond, W. W. Barkmeier, T. M. Wilwerding, "Effect of porcelain surface treatments on bond strengths of composite resin bonded to porcelain', J. Prosthet. Dent. 72 (1994) 355-359.

[29] R. Friederich, M. Kern, "Resin bond strength of densely sintered alumina ceramic", Int. J. Prosthodont 15 (2002) 333-338.

[30] M. Madani, F. C. Chu, A. V. McDonald, R. J. Smales, "Effects of surface treatments on shear bond strengths between a resin cement and an alumina core", J. Prosthet. Dent. 83 (2000) 644-647.

[31] G. Saygili, S. Sahmali, "Effect of ceramic surface treatment on the shear bond strengths of two resin luting agents to all-ceramic materials", J. Oral Rehabil. 30 (2003) 758-764.

[32] K. Kamada, K. Yoshida, M. Atsuta, "Effect of ceramic surface treatments on the bond of four resin luting agents to a ceramic material", J. Prosthet. Dent. 79 (1998) 508-513.

[33] W. Hooshmann, I. Nergiz, M. Özcan, P. Schmage, U. Platzer, "Influence of conditioning methods on bond strengths between brackets and ceramic surfaces", J. Dent. Res. 79 (2000) 2333 (abstract).

[34] A. Della Bona, R. Van Noort, "Ceramic surface preparations for resin bonding', Am. J. Dent. 11 (1998) 276280.

[35] Z. Z. Li, J. E. Code, W. P. Van der Merwe, "Er:YAG laser ablation of enamel and dentin of human teeth: determination of ablation rates at various fluences and pulse repetition rates", Lasers Surg. Med. 12 (1992) 625-630.

[36] C. P. Trajtenberg, P. N. R. Pereira, J. M. Powers, "Resin bond strength and micromorphology of human teeth prepared with an Erbium:YAG laser", Am. J. Dent. 17 (2004) 331-336.

[37] H. Akin, F. Tugut, G. Emine Akin, U. Guney, B. Mutaf, "Effect of Er:YAG laser application on the shear bond strength and microleakage between resin cements and Y-TZP ceramics", Lasers Med. Sci. 27 (2012) 333-338.

[38] U. Keller, R. Hibst, Er:YAG Laser Effects on Oral Hard and Soft Tissue, The laser in Dentistry by L. J. Miserendino, R. M. Pick, Ed. Quintessence Publishing Co, INC. (1995).

[39] H. Jelínková, T. Dostálová, L. Doležalová, O. Krejsa, K. Hamal, J. Kubelka, S. Procházka, Comparison of preparation speed of Er:YAG laser and conventional drilling machine, In Lasers in Dentistry III, Ed: H. A. Wigdor, J. D. B. Featherstone, P. Rechmann, SPIE 2973 (1997) 2-10.

[41] Y. Shigetani, A. Okamoto, N. Abu-Bakr, M. Iwaku, "A study of cavity preparation by Er:YAG laser-observation of hard tooth structures by laser scanning microscope and examination of the time necessary to remove caries", Dent. Mater. J. 21 (2002) 20-31.

[41] M. Ş. Akyıl, A. Yılmaz, F. Bayındır, Z. Y. Duymuş, "Microtensile bond strength of resin cement to a feldspathic ceramic", Photomed. Laser Surg. 29 (2011) 197-203.

[42] N. Ozturk, F. Aykent, "Dentin bond strengths of two ceramic inlay systems after cementation with three different techniques and one bonding system", J. Prosthet. Dent. 89 (2003) 275-281.

[43] M. B. Blatz, A. Sadan, C. Maltezos, U. Blatz, D. Mercante, J. O. Burgess, "In vitro durability of the resin bond to feldspathic ceramics", Am. J. Dent. 17 (2004) 169172.

[44] D. M. Schweitzer, G. R. Godstein, J. L. Ricci, N. R. F. A. Silva, E. L. Hittelman, "Comparison of bond strength of a pressed ceramic fused to metal versus feldspathic porcelain fused to metal", J. Prosthodont. 14 (2005) 239-247.

[45] A. Della Bona, R. Van Noort, "Shear versus tensile bond strength of resin composite bonded to ceramic", J. Dent. Res. 74 (1995) 151-156.

[46] K. J. Anusavice, P. H. DeHoff, C. W. Fairhurst, "Comparative evaluation of ceramic-metal bond test using finite element stress analysis", J. Dent. Res. 59 (1980) 608613

[47] R. Van Noort, S. Noroozi, I. C. Howard, G. Cardew, "A critique of bond strength measurements", J. Dent. 17 (1989) 61-67.

[48] F. G. Panah, S. M. M. Rezai, L. Ahmadian, "The influence of ceramic surface treatments on the micro-shear bond strength of composite resin to IPS Empress 2", J. Prosthodont. 17 (2008) 409-414.

(Rec. 06/10/2014, Ac. 06/04/2015) 